\title{
Pembentukan Tasawur dan Kesan terhadap Pembangunan Tradisi Keilmuan Islam
}

\author{
The Formation of Islamic Worldview and Its Impact on \\ the Tradition of Islamic Knowledge
}

MOHD SHUKRI HANAPI ${ }^{1}$

\begin{abstract}
This article attempts to discuss the origins of which led to the formation of an Islamic worldview from its grassroots. Islamic worldview has proclaimed by Rasulullah SAW in beginning of era Makkiyyah and Madaniyyah through the delivery of revelation of Allah SWT. Started from there, it has evolved from one stage to another stage until successfully built a strong tradition of Islamic scholarship. The questions raised are, how the Islamic worldview is formed in a relatively long period of time which is about 23 years? What is the effect of the formation of the Islamic knowledge traditions? To answer both of these questions, this article discusses the following three parts. First, to examine the formation of the Islamic worldview. Second, to look at the structure of knowledge formation in the Islamic worldview. Third, to analyze the development of traditional Islamic sciences as a result of the existence of knowledge structures in the Islamic worldview. It is created by focusing the discussion on prominent views of Muslim scholars. All of these views are based on the existing studies. Finally, this article concludes that the development of traditional Islamic sciences is the result of the worldview formation through a revelation by Allah SWT.
\end{abstract}

Keywords: development, Islamic knowledge, Islamic worldview, tradition.

Tasawur Islam merupakan gambaran bentuk Islam yang hakiki. Ia menjelaskan secara keseluruhan prinsip-prinsip asas Islam secara benar dan lengkap, sehingga bersebati di dalam diri orang yang memahaminya (Muhammad Syukri, 2003a: 21 \& 2008: 2). Maksud tasawur Islam yang dikemukakan oleh Muhammad Syukri Salleh (2003a \& 2008) ini adalah sama dengan apa yang dikemukakan oleh beberapa penulis lain, seperti Haron Din (1992: 3), Mohd. Kamal Hassan (1993) dan Ramli Awang (1997: 6). Menurut mereka, tasawur Islam ialah gambaran atau penjelasan yang komprehensif dan benar mengenai Islam.

Pembentukan tasawur Islam ini bermula daripada penerimaan dan penyebaran wahyu Allah SWT oleh Rasulullah SAW di Mekah. Setiap kali Rasulullah SAW menerima wahyu berupa ayat-ayat al-Quran, Baginda menyebarkan dan menjelaskannya kepada masyarakat. Sebenarnya perkara ini lebih jelas dilihat daripada proses pembentukan perkara-perkara pokok yang merupakan bahagian terpenting dalam tasawur Islam. Perkara-perkara pokok ini ialah akidah, ibadah dan akhlak. Daripada ketiga-tiga perkara pokok ini pula, akidah merupakan tunjangnya (Sidek Baba 2006: 186-187).

${ }^{1}$ Mohd Shukri Hanapi, lecturer at Centre for Islamic Development Management Studies (ISDEV), School of Humanities, Universiti Sains Malaysia, Pulau Pinang, Malaysia. Email: hshukeri@yahoo.com. 
Selain itu, terdapat penulis-penulis lain, seperti al-Mawdudi (1985), Abdullah Yasin (1990: 87), Abdul Halim El-Muhammady (1992: 5), Ramli Awang (1997: 15-16), Muhammad Syukri Salleh (2002:56, 2003a:21 \& 2003b:4), Muhammad Nasri Md Hussain dan Ab. Aziz Yusof (2005: 29), dan Ahmad Mohd Salleh (2004: 22) yang juga mengemukakan tiga perkara pokok dalam tasawur Islam. Tetapi tiga perkara pokok tersebut ialah Allah SWT sebagai Pencipta, manusia sebagai hamba dan khalifah Allah SWT, dan alam semesta sebagai makhluk. Meskipun ia nampak berbeza daripada ketiga-tiga perkara pokok yang dinyatakan dalam kertas kerja ini, namun pada hakikatnya ia adalah sama sahaja. Meyakini Allah SWT sebagai Pencipta dan manusia serta alam semesta sebagai makhluk termasuk dalam bahagian akidah. Manusia yang memperhambakan diri kepada Allah SWT termasuk dalam bahagian ibadah. Begitulah juga dengan alam semesta yang sentiasa berzikir kepada Allah SWT, ia pun termasuk dalam bahagian ibadah ini. Selain itu, akhlak pula merupakan perkara yang perlu dijaga dalam hubungan manusia dengan Allah SWT, manusia sesama manusia, dan juga ketika manusia menguruskan alam semesta ini. Sebenarnya, proses pembentukan perkara-perkara pokok yang membawa kepada pembentukan tasawur Islam ini telah memakan masa yang agak lama, iaitu lebih kurang 23 tahun. Persoalannya, bagaimanakah tasawur Islam itu terbentuk? Hasil daripada pembentukannya itu, apakah pula kesannya terhadap pembangunan tradisi keilmuan Islam? Untuk menjawab kedua-dua persoalan ini, maka makalah ini akan memfokuskan kepada pandangan tokoh-tokoh pemikir Islam. Semua pandangan ini ditinjau berdasarkan penulisan-penulisan yang sedia ada.

\section{Pembentukan Tasawur Islam}

Pembentukan tasawur Islam dapat dilihat dari sudut kronologi penurunan wahyu dan pentafsiran Rasulullah SAW tentang wahyu itu. Ertinya, hal ini bermula daripada peranan Rasulullah SAW dalam menyebarkan dan menjelaskan wahyu itu. Sebenarnya era Mekah merupakan era yang sangat penting berhubung pembentukan tasawur Islam ini. Tambahan pula kebanyakan surah dalam al-Quran diturunkan di Mekah. Menurut al-Tantawi (2003: 29), sebanyak 82 surah daripada 114 surah al-Quran diturunkan di Mekah. Jelas di sini bahawa pembentukan tasawur Islam bermula sejak penurunan wahyu di Mekah lagi.

Oleh kerana sebahagian besar al-Quran itu diturunkan di Mekah, maka perbincangan tentang penurunan wahyu di Mekah itu boleh dibahagikan kepada dua era pula, iaitu era awal dan era akhir penurunan al-Quran di Mekah. Wahyu yang diturunkan pada era awal penurunan al-Quran di Mekah itu mengandungi konsep-konsep tentang ketuhanan dan keimanan kepada Allah SWT, hari akhirat, hari pembalasan, penciptaan alam, syurga dan neraka, balasan baik dan buruk, dan sebagainya. Semua ini merupakan perkara asas tasawur Islam yang paling penting. Wahyu yang diturunkan pada era akhir penurunan al-Quran di Mekah pula telah memperkenalkan konsep-konsep yang lebih luas dan abstrak, seperti konsep ilmu, kenabian, agama, ibadah dan sebagainya (Acikgenc 1996: 71-72). Menurut Hamid Fahmy Zarkasyi (2004), penurunan wahyu dalam kedua-dua era ini sangat penting terhadap proses pembentukan tasawur Islam. Paling tidak terdapat dua sebab kepentingannya. Pertama, sebahagian besar al-Quran diturunkan di Mekah. Kedua, kandungan wahyu dan penjelasan Nabi Muhammad SAW serta kesungguhan masyarakat Muslim dalam memahami wahyu pada ketika itu telah membentuk struktur konsep baru tentang dunia. Ia merupakan elemen penting dalam tasawur Islam.

Berhubung kepentingan kedua ini, Izutsu (1964: 36-38) menjelaskan bahawa sebelum kedatangan Islam struktur konsep tentang dunia telah dipengaruhi oleh tasawur masyarakat pra-Islam (Jahiliah). Kedatangan Islam telah berjaya merubah struktur konsep 
tentang dunia yang dibentuk oleh tasawur masyarakat Jahiliah itu. Ia kemudiannya digantikan dengan struktur konsep baru tentang dunia yang dibawa oleh Islam. Misalnya, pada zaman Jahiliah konsep karam bermaksud kemuliaan kerana memiliki harta dan anak yang ramai. Kedatangan Islam telah merubah konsep karam menurut tasawur Jahiliah itu menjadi kemuliaan kerana ketinggian ketakwaan kepada Allah SWT. Demikian ini berdasarkan maksud firman Allah SWT:

Wahai manusia, sesungguhnya Kami menciptakan kamu dari seorang lelaki dan seorang perempuan dan menjadikan kamu berbangsa-bangsa dan bersuku-suku supaya kamu saling kenal-mengenali. Sesungguhnya orang yang paling mulia di antara kamu di sisi Allah ialah orang yang paling takwa di antara kamu. Sesungguhnya Allah Maha Mengetahui lagi Maha Mengenali (al-Quran, al-Hujurat 49:13).

Selain itu, wahyu yang diturunkan pada era Madinah mengandungi tema-tema umum yang berbentuk penyempurnaan ritual peribadatan, rukun Islam, sistem hukum yang mengatur hubungan individu, keluarga dan masyarakat. Termasuk juga di sini ialah hukumhukum tentang jihad, perkahwinan, pewarisan, hubungan umat Islam dengan golongan bukan Islam dan sebagainya (Qadhi 1999: 100-101). Secara keseluruhannya, semua tema ini berkait rapat dengan kehidupan masyarakat Islam. Meskipun begitu, didapati tema-tema wahyu yang diturunkan pada era Madinah ini masih tidak terpisah daripada tema-tema wahyu yang diturunkan di Mekah. Ia dilihat masih membincangkan tema-tema wahyu yang diturunkan pada era Mekah. Misalnya, era Mekah menekankan beberapa prinsip dasar akidah yang inti patinya adalah konsep ketuhanan, sedangkan era Madinah pula mengembangkan prinsip-prinsip itu ke dalam konsep-konsep sosial. Pengembangan ini lebih berbentuk aplikasi-sosialisasi.

\section{Pembinaan Struktur Ilmu Pengetahuan dalam Tasawur Islam}

Serentak dengan pembentukan tasawur Islam itu, terbentuk juga struktur ilmu pengetahuan di dalamnya. Berhubung pembentukan struktur ilmu pengetahuan dalam tasawur Islam ini, Hamid Fahmy Zarkasyi (2004) menyatakan pembentukan struktur konsep dunia bermula pada era Mekah, sedangkan penyusunan struktur ilmu pengetahuan yang berperanan penting dalam menghasilkan kerangka konsep keilmuan dalam tasawur Islam bermula pada era Madinah. Sebenarnya dalam era Madinah, wahyu yang diturunkan dan dijelaskan oleh Rasulullah SAW itu telah mengandungi struktur asas tasawur, seperti struktur-struktur tentang kehidupan, dunia, ilmu pengetahuan, etika dan manusia. Semua itu sangat berpotensi untuk menggerakkan kegiatan keilmuan sehingga lahir beberapa istilah yang dikembangkan daripada kosa kata al-Quran dan hadis Nabi SAW. Misalnya, istilah 'ilm (pengetahuan), fiqh (pemahaman), usul (asas-asas ilmu), ijtihad (usaha atau kesungguhan), ijma' (persetujuan sebulat suara), qiyas (membandingkan), 'aql (akal), idrak (mengerti atau memahami), tadabbur (meneliti, memahami dan mengamalkan), tafakkur (berfikir), hikmah (kebijaksanaan atau kearifan), yaqin (yakin), wahy (wahyu), tafsir (menjelaskan), ta'wil (mentafsirkan), 'alam (alam semesta), kalam (percakapan), nutq (percakapan), zann (sangkaan), wahm (ragu-ragu), haqq (kebenaran), batil (kebatilan), haqiqah (realiti), 'adam (ketiadaan), wujud (ada), sabab (sebab), khalq (makhluk), khulq (akhlak), dahr (sepanjang tahun), sarmad (berkekalan), zaman (masa), azal (azali), abad (kekal), fitrah (naluri), kasb (usaha), khayr (kebaikan), ikhtiyar (usaha), syarr (kejahatan), halal (sah atau dibenarkan), haram (tegahan), wajib (kemestian), iradah (kehendak) dan 
sebagainya (Hamid 2004). Demikian ini sudah memadai untuk membuktikan kewujudan kerangka konsep keilmuan. Dari sinilah lahirnya elemen-elemen epistemologi yang terdapat dalam tasawur Islam itu.

Perbincangan ini juga memperlihatkan pada era Madinah struktur ilmu pengetahuan dalam fikiran umat Islam ketika itu telah pun wujud. Secara tidak langsung, perkara ini membuktikan wujudnya struktur ilmu pengetahuan dalam tasawur Islam, meskipun asas kepada beberapa konsep ilmu telah wujud pada era Mekah.

Berasaskan kerangka konseptual ini, jelas bahawa ilmu pengetahuan yang terbentuk daripada istilah-istilah keilmuan dalam Islam adalah lahir daripada tasawur dan epistemologi Islam (al-Quran dan hadith). Ia sama sekali tidak dibawa daripada kebudayaan atau tasawur lain. Pernyataan ini jelas bertentangan dengan pandangan sebilangan penulis sejarah Islam dari Barat, seperti De Boer (1994: 28-29), Myers (1964: 7-8), Gullimaune (1948: 239) dan O'Leary (1963: viii). Mereka menganggap sains dalam Islam bukan sesuatu yang asli daripada ajaran Islam. Tanggapan ini seolah-olah tidak ada suatu perkara pun yang berasal daripada Islam. Dengan kata lain, mereka menganggap Islam tidak menyumbang sesuatu apa pun kecuali hasil penterjemahan karya-karya Yunani sahaja.

Tanggapan penulis-penulis sejarah Islam dari Barat ini telah mempengaruhi pemikiran sebilangan penulis lain, seperti Walzer (1967: 123-130), Fakhry (1983: viii-xi) dan Watt (1985: 33-64 \& 69-128). Kesemua pandangan itu sudah tentu berdasarkan pada kerangka tertentu yang tidak menganggap atau menafikan wujudnya tasawur Islam dan kerangka konsep keilmuan di dalamnya. Jelasnya mereka mungkin tidak menyedari atau sengaja menafikan tentang kewujudan tasawur Islam yang merupakan asas kepada pembangunan tradisi intelektual Islam.

\section{Pembangunan Tradisi Keilmuan Islam}

Pembentukan struktur ilmu pengetahuan dalam tasawur Islam sebagaimana yang dijelaskan sebelum ini, telah menyumbang kepada pembangunan tradisi keilmuan Islam. Pada era ini penjelasan yang lebih terperinci dan mendalam tentang tradisi keilmuan Islam amat diperlukan (Hamid 2004). Oleh sebab tradisi keilmuan Islam itu memerlukan penglibatan masyarakat secara menyeluruh, maka kewujudan tradisi keilmuan Islam perlu dibuktikan. Untuk membuktikannya pula Alparslan Acikgenc (1996: 71-72) berpendapat terdapat dua perkara yang perlu dijelaskan. Pertama, tentang kewujudan komuniti ilmuwan dan proses pembangunannya pada awal abad pertama dalam Islam; dan kedua, tentang kewujudan kerangka konseptual keilmuan Islam yang dijadikan sebagai kerangka kerja dalam tradisi keilmuan Islam itu.

Bagi memperkukuhkan pendapat Alparslan Acikgenc (1996) ini, al-'Umariy (2000: 106-107) dan Hamid Fahmy Zarkasyi (2004) menyatakan kewujudan tradisi keilmuan Islam ini dapat dibuktikan dengan sejarah kewujudan masyarakat ilmuwan atau kelompok pelajar, seperti ahl al-Suffah di Madinah. Mereka adalah kelompok pelajar yang mendiami pelantar yang ditinggikan atau pangkin. Pelantar ini pula terletak di serambi masjid Nabi SAW dan dibiarkan terbuka pada tiga sisinya. Selain al-Suffah, ia dikenali juga sebagai alZillah yang bermaksud pelindung. Tempat ini telah dibina atas arahan Rasulullah SAW sendiri setelah Allah SWT perintahkan kiblat umat Islam ditukarkan dari Bayt al-Maqdis ke Ka'abah di Masjid al-Haram di Mekah. Dengan pertukaran arah kiblat ini, maka dinding kiblat pertama menjadi dinding belakang masjid Nabi SAW. Nabi SAW memerintahkan agar di atasnya dibina siling lalu kemudiannya dipanggil al-Suffah atau al-Zillah itu. Secara lebih jelas lagi, Ibn Jubayr menyatakan bahawa al-Suffah ini merujuk kepada sebuah rumah di hujung Quba'. Di situ ahl al-Suffah tinggal beramai-ramai. Al-Samhudi pula menyatakan, 
rumah itu dikenali sebagai al-Suffah apabila ahli al-Suffah berpindah ke situ (al-'Umariy 2000: 100-101; Muhammad Syukri Salleh 2000: 18-19). Besarnya tidak dapat dipastikan. Tetapi mengikut Muslim (1983: 1051, Hadis No. 94), Rasulullah SAW pernah menggunakannya untuk mengadakan jamuan majlis perkahwinan yang dihadiri oleh 300 orang. Sebahagian mereka duduk di satu daripada bilik-bilik yang berdekatan dengan masjid, yang menjadi kepunyaan isteri-isteri Rasulullah SAW. Di al-Suffah inilah kandungan ayat-ayat al-Quran dan hadis-hadis Rasulullah SAW dikaji melalui kaedah pengajaran dan pembelajaran yang efektif. Berhubung bilangan ahli dalam komuniti ilmu ini, Abu Nu'aym (1938: 339-341) menyatakan bilangan ahli dalam komuniti ilmu ini berbeza-beza dari satu waktu ke satu waktu yang lain. Ia bertambah apabila ada delegasi yang datang ke Madinah. Menjadi berkurang apabila orang-orang luar itu pergi. Tetapi bilangan ahli yang tetap ialah sekitar 70 orang sahaja.

Menurut Hajji Khalifah, Abu Nu'aym (1938) adalah satu-satunya ilmuan yang berusaha menyenaraikan nama-nama ahl al-Suffah. Beliau meriwayatkan perkara ini daripada sumber yang lebih awal, yang tidak disebutnya. Ia mungkin dipetik daripada buku Abu 'Abd al-Rahman al-Sulami (m. $412 \mathrm{H}$ ) yang menulis tentang ahl al-Suffah (dipetik dari al-'Umariy 2000: 103). Walau bagaimanapun, perkara yang dikaji pada era ini masih di tahap sederhana. Objek kajiannya pula tertumpu pada wahyu secara khusus, namun perbincangannya agak luas dan kompleks. Ia tidak dapat disamakan dengan perkara yang dibincangkan di Ionia. Menurut pengkaji Barat, Ionia merupakan tempat kelahiran tradisi intelektual Yunani dan kebudayaan Barat. Jelas di sini bahawa ahl al-Suffah adalah gambaran terbaik berhubung kegiatan pengajaran dan pembelajaran dalam Islam. Ia merupakan tonggak awal tradisi intelektual dalam Islam. Hasil daripada kegiatan ini adalah munculnya individu-individu yang mempunyai kepakaran dalam bidang hadis Nabi SAW, seperti Abu Hurayrah, Abu Dharr al-Ghiffari, Salman al-Farisi, 'Abd Allah Ibn Mas'ud dan sebagainya. Ribuan hadis telah berjaya dikaji dan dipelajari oleh ahl al-Suffah ini (Hamid 2004).

Kegiatan awal pengkajian wahyu dan hadis ini telah diteruskan oleh generasigenerasi berikutnya. Menurut Hamid Fahmy Zarkasyi (2004), tidak lebih dari dua abad telah muncul pula ilmuwan-ilmuwan terkenal dalam pelbagai bidang keagamaan, seperti Muhammad Ibn al-Hanafiyyah (m. 81 H/700 M), Ma'bad al-Juhani (m. 84 H/703 M), 'Umar Ibn 'Abd al-'Aziz (m. 102 H/720 M), Wahb Ibn Munabbih (m. 110 H/719 M), Hasan al-Basri (m. 110 H/728 M), Ghaylan al-Dimasyqi (m. 123 H/740 M), Ja'far al-Sadiq (m. 148 H/765 M), Abu Hanifah (m. 150 H/767 M), Malik bin Anas (m. 179 H/796 M), Abu Yusuf (m. 182 H/799 M), al-Syafi'i (m. 204 H/819 M) dan lain-lain. Kerangka kerja ilmu yang diguna pakai pada zaman awal pembangunan tradisi keilmuan ini sudah tentu adalah kerangka konsep keilmuan yang terdapat dalam tasawur Islam. Bukti kewujudan kerangka konseptual ini adalah usaha-usaha para ilmuwan untuk membina beberapa istilah keilmuan yang agak rumit. Seperti yang dijelaskan sebelum ini, kebanyakan istilah tersebut telah diambil daripada kosa kata dalam al-Quran dan hadis Nabi SAW. Semua ini sebagai bukti kukuh menunjukkan wujudnya kerangka konsep keilmuan Islam.

Berdasarkan perbincangan sebelum ini, makalah ini merumuskan bahawa tasawur Islam itu terbentuk daripada wahyu yang diturunkan oleh Allah SWT kepada Nabi Muhammad SAW. Di dalamnya terkandung kerangka konsep keilmuan Islam yang kukuh dan terbina berasaskan wahyu. Sebenarnya perkara inilah yang menjadi pemisah antara konsep keilmuan Jahiliah dengan konsep keilmuan Islam. Meskipun dilihat ada beberapa aspek dari konsep keilmuan Jahiliah itu masih digunakan dalam Islam, tetapi akar umbinya telah dirombak. Dengan kata lain, sesuatu yang sama dari sudut pandangan akal manusia, tetapi tidak sama dari sudut tasawurnya. Tidak mungkin Islam mengguna pakai sesuatu 
dari konsep keilmuan Jahiliah itu secara bulat-bulat tanpa ada perubahan pada akar umbinya. Jelas di sini bahawa tasawur Islam itu merupakan tunjang, asas dan acuan yang membawa kepada pembangunan tradisi keilmuan dalam Islam.

\section{References}

Abdul Halim El-Muhammady. 1992. Tasawwur Islam. Dlm. Abdul Halim El-Muhammady (pnyt.) Dinamika Dakwah Suatu Perspektif Dari Zaman Awal Islam Hingga Kini. Selangor: Budaya Ilmu Sdn. Bhd.

Abdullah Yasin. 1990. Hakikat Dua Kalimah Syahadat. Kuala Lumpur: Nurin Enterprise.

Abu Nu'aym, Ahmad Ibn 'Abd Allah al-Asbahani. 1938. Hilyah al-Awliya'. Vol. 1. Egypt: AlSaadah Press.

Acikgenc, A. 1996. Islamic Science Toward Definition. Kuala Lumpur: International Institute of Islamic Thought and Civilization (ISTAC).

Ahmad Mohd. Salleh. 2004. Pendidikan Islam Falsafah, Sejarah dan Kaedah Pengajaran dan Pembelajaran. Selangor: Fajar Bakti Sdn. Bhd.

De Boer, T. J. 1994. The History of Philosophy in Islam. Terj. Jones, Edward R. United Kingdom: Curzon Press, Richmond.

Fakhry, Majid. 1983. A History of Islamic Philosophy. New York: Columbia University Press.

Gullimaune, A. 1948. Philosophy and Theology in the Legacy of Islam. United Kingdom: Oxford University Press.

Hamid Fahmy Zarkasyi. 2004. Islam sebagai Pandangan Hidup (Kajian Teoritis Dalam Merespon Perang Pemikiran). Diakses pada 11 June 2010, daripada http://pondokshabran.org/index.php?option=com_content\&task=view\&id=37\&Ite mid=17.

Hamid Fahmy Zarkasyi. 2011. Pandangan Hidup, Ilmu Pengetahuan dan Pendidikan Islam. Diakses pada 17 May 2011, daripada http://fajrulislam.word press.com/ 2011/01/17/pandangan-hidup-ilmu-pengetahuan-dan-pendidikan-islam/.

Haron Din. 1992. Tasawwur Islam. Shah Alam: Pustaka Hizbi.

Izutsu, T. 1964. God and Man in the Koran: Semantics of the Koranic Weltanschauung. Tokyo: Keio Institute of Cultural Studies.

Al-Mawdudi, Abu al-A'la. 1985. Cara Hidup Islam. Terj. Wan Salim Muhammad Nur. Shah Alam: Dewan Pustaka Fajar Sdn. Bhd.

Mohd. Kamal Hassan. 1993. The Islamic World-View, kertas kerja yang dibentangkan di Seminar On Islam and Its World-View: An American Perception, anjuran Institut Kefahaman Islam Malaysia (IKIM) dan The Malaysian-American Commission on Education Exchange, di Hotel Pan Pasific, Kuala Lumpur, 19 August.

Muhammad Nasri Md Hussain \& Ab. Aziz Yusof. 2005. Pengurusan Sumber Manusia dari Perspektif Islam. Petaling Jaya: Pearson.

Muhammad Syukri Salleh. 2002. Pembangunan Berteraskan Islam. Kuala Lumpur: Utusan Publications \& Distributors Sdn. Bhd.

Muhammad Syukri Salleh. 2003a. 7 Prinsip Pembangunan Berteraskan Islam. Kuala Lumpur: Zebra Editions Sdn. Bhd.

Muhammad Syukri Salleh. 2003b. Pengurusan Pembangunan Berteraskan Islam: Konsep dan Perkaedahan (Siri Syarahan Umum Perlantikan Profesor). Pulau Pinang: Penerbit Universiti Sains Malaysia.

Muhammad Syukri Salleh. 2008. Keperluan, Kedudukan dan Hala Tuju Kaedah Penyelidikan Berteraskan Islam, Pemikir, Bil. 54, October-December. hlm. 133-164. 
Muhammad Syukri Salleh. 2008. Pembangunan Zaman Rasulallah s.a.w.: antara Kemiskinan dan Kekayaan. Pulau Pinang: Pejabat Mufti Kerajaan Negeri Pulau Pinang.

Muslim, Abi al-Husayn Muslim bin al-Hujjaj al-Qusyayri al-Naysaburi. 1983. Sahih Muslim, Jld. 2. Beirut: Dar al-Fikr li al-Taba'ah wa al-Nasyr wa al-Tawzi'.

Myers, E. A. 1964. Arabic Thought and the Western World. New York: Fredrick Ungar Publishing Co.

O'Leary, De Lacy. 1963. Arabic Thought and Its Place in History. London: Routledge \& Kegan Paul Ltd.

Qadhi, Abu Ammar Yasir. 1999. An Introduction to the Science of the Qur'an. Birmingham: AlHidayah Publishing and Distribution.

Ramli Awang. 1997. Tasawwur Rabbani Menurut Al-Qur'an dan Al-Sunnah. Cet. Pertama. Kuala Lumpur: Al-Hidayah Publication.

Sidek Baba. 2006. Pendidikan Rabbani. Selangor: Karya Bestari Sdn. Bhd.

Tantawi, Muhammad Sayyid. 2003. Mabahith fi 'Ulum al-Qur'an. Kuala Lumpur: Kementerian Pendidikan Malaysia.

Al-'Umari, Akram Diya'. 2000. Masyarakat Madani di Zaman Nabi. Transl. Zainab Abdul Kadir. Selangor: Thinker's Library Sdn. Bhd.

Walzer, R. 1967. "Islamic Philosophy and Theology in the Legacy of Islam", Dlm. Radhakrishnan (pnyt.). History of Philosophy, Esatern and Western. London: George Allan \& Unwin Ltd.

Watt, M.W. 1985. Islamic Philosophy and Theology. Edinburgh: University of Edinburgh Press. 